\title{
N-Myc Proto-Oncogene Protein
}

National Cancer Institute

\section{Source}

National Cancer Institute. N-Myc Proto-Oncogene Protein. NCI Thesaurus. Code

C17379.

$\mathrm{N}$-myc proto-oncogene protein (464 aa, $\sim 50 \mathrm{kDa}$ ) is encoded by the human MYCN gene.

This protein plays a role in the regulation of transcription and DNA binding. 